\title{
Valuing Wetland Ecosystem in Ethiopia an Empirical Evidence with Choke Mountain: Application of Choice Experiment
}

Melaku Tarekegn Takele ( $\nabla$ melakutar06@gmail.com )

University of Gondar College of Business and Economics

\section{Belaynesh Awoke}

Debre Tabor University

Eshetie Woretaw Merid

University of Gondar College of Business and Economics

\section{Research}

Keywords: Choice experiment, mixed logit model, wetland ecosystem service, willingness to pay

Posted Date: August 11th, 2020

DOI: https://doi.org/10.21203/rs.3.rs-56131/v1

License: (1) (i) This work is licensed under a Creative Commons Attribution 4.0 International License.

Read Full License 


\title{
Valuing wetland ecosystem in Ethiopia an empirical evidence with Choke mountain: Application of choice experiment ${ }^{1}$ Melaku Tarekegn Takele*, ${ }^{2}$ Belaynesh Awoke, ${ }^{1}$ Eshetie Woretaw Merid
}

${ }^{1}$ School of Economics, College of Business and Economics, University of Gondar, P.O.BOX 196, Gondar, Ethiopia, Email: melakutar06@gmail.com and ESHEWOW@gmail.com

${ }^{2}$ Department of Economics, Faculty of Business and Economics, Debre Tabor University, Gondar, Ethiopia, Email, belayawoke86@gmail.com

* Corresponding author

\begin{abstract}
Ecosystem services have not market price. In Ethiopia, choke mountain wetland ecosystem has major contribution for providing water, regulating climate, and offering recreational. Valuing this natural resource helps to protect it from damage. The objective of the study is to value choke mountain wetland ecosystem by using choice experiment. To value it the attributes are biodiversity, recreational service, water availability, job opportunity, and monetary payment. Primary data was collected from 270 sample households. Both descriptive and econometrics analysis were conducted. The study found that households had good awareness about the choke mountain wetland ecosystem services. Mixed logit models were used for valuation, and all attributes are significant to affect the probability of choosing an alternative scenario. The study found that households gave higher value for biodiversity improvement than the rest and water availability is the least preferable attributes. The total WTP for the first and second alternatives was 7,133,034.216 and 7,031,211.146 respectively; it was high in the second alternative. Moreover, compensating surplus which reflect overall willingness to pay for a change from the status quo to alternative improvement scenarios were estimated. Estimated results for high improvement scenario and medium improvement scenario were ETB 2,119,457.028 and 1,955,828.606 respectively.
\end{abstract}

Key Words: Choice experiment; mixed logit model, wetland ecosystem service, willingness to pay 


\section{Introduction}

Environmental resources are vital for human by providing recreational opportunities, improving health situation, facilitate production of goods and services. However, quantify their value is not easy. Wetland ecosystems, are one of environmental resources (Dagnew \& Aboytu, 2015; Ramachandra et al,. 2004). It contribute up to $40 \%$ of annual global ecosystem services (Zedler \& Kercher, 2005). It is estimated that wetlands cover at least $6 \%$ of the earth surface (Cools, Johnston, Hattermann, Douven, \& Zsuffa, 2013) and 4\% of Africa's land surface (Ibrahim \& Minwyelet, 2018). Different types of wetlands cover around $2 \%$ of the total surface area of Ethiopia (Getinet, 2017; Ibrahim \& Minwyelet, 2018).

Though wetlands area coverage in Ethiopia is trivial, they are productive and vital sources of water during dry season for both domestic and wild animals (Tadessse \& Solomon, 2014). They provide, regulating cultural services to local people (Ibrahim \& Minwyelet, 2018). They are spread in central highlands, rift valley and southwest borders of the country (Israel \& Timar, 2018).

Valuing of wetland ecosystems can be performed through direct, indirect market, and survey-based valuation mechanism (Davidson et al., 2006). For this purpose, choice experiment is preferable because the ability of estimating use and non-use values of choice experiment of each attribute which are provided by mountain choke wetland ecosystems.

According to the study of Getnet (2012) the attribute of choke mountain wetland ecosystem is water availability. The level of attribute is based on number of rainy seasons. However, value of water availability is not estimated exactly. The other reason behind of the study is the mountain choke wetland ecosystem has a great potential to create job opportunity for the young people. Farming based living style of the community is cause for degradation of mountain, valuing this attribute helps to find a way to conserve choke mountain wetland ecosystem. By considering the above situations, the study starts to value choke mountain wetland ecosystem using four qualitative and one quantitative attribute. Each of the attribute is leveled reasonably.

\section{Theoretical framework of wetlands ecosystem services}

Wetlands are transitional lands between and other water bodies (Ramachandra, Rajinikanth, \& Ranjini, 2004). 
Ecosystem can be defined as dynamic collections of plants, animals, and microorganisms interacting with each other and their abiotic environment. Wetland ecosystem services offer a wide variety of tangible and intangible benefits to large numbers of people (McCartney, Rebelo, Sellamuttu, \& Silva, 2010).

The distinction between ecosystem functions and services matters. This is because from an economic point of view what is valued by people are the end products of the various ecological processes and functions, namely the ecosystem services which affect peoples' welfare (Groot et al., 2002). Based on neoclassical economic theory, market prices are usually an adequate reference for the value that society places on goods and services (Dora \& Francisco, 2011), but with environmental goods and services, market imperfections distort their real prices or values, plus the value that individuals place on them cannot be readily observed (Barbier, Acreman, Knowler, \& Bureau, 1997).

Mostly environmental services are unrecognized and undervalued because many of services are forms of public good, accruing outside monetary systems (McCartney, Rebelo, Sellamuttu, \& Silva, 2010). Thus, valuation of environmental resources assists to determine how much people are willing to pay for environmental goods and services, and how much better or worse off because of changes in their supply (Emerton, 2016).

Choice experiment is a recent innovation in stated preference techniques. It combines the characteristics theory of value (Lancaster, 1966) and random utility theory (McFadden, 1974). CEM has distinct advantages over other stated preference techniques; it is able to value multiple attributes. The repeated choices in CE allow for internal validity yield information concerning the consistency of individual responses (Gebretsadik, 2014). It is used to reduce potential biases of contingent valuation method, several response difficulties such as strategic behavior, protest bids, and yeah saying (Getahun, 2010).

\section{Empirical framework of valuing wetlands ecosystem services}

There are different studies concerned with ecosystem valuation to value it. On the area of national park, Ali (2011) studied to value Semen Mountain National Park by using TCM and CEM. From the TCM, the expected aggregate annual recreational economic benefit gained by visitors of the site is estimated at Birr 48,562,086.4 (approximately US\$2,943,156.7). 
Andualem (2011) investigate valuation of non-marketable goods and services in case of Addis Ababa wild life Zoo Park with application of individuals' travel cost method (ITCM) and Double Dichotomous Contingent Valuation Method (DDCVM). The study used seemingly unrelated bivariate probit model to derive the demand function for recreational use value of wildlife and truncated probit model to estimate the non-use value contribution of wildlife.

Getahun (2011) studied WTP for improved liquid waste treatment in Addis Ababa and its determinants using choice modeling approach. The households prefer a cheaper alternatives and presence of status quo bias; estimated mean willingness to pay per month was 22.14 and 4.60 Ethiopian Birr (ETB) for high quality and additional quantity of treated liquid waste, respectively.

Gebretsadik (2014) investigated the valuation of protecting urban river water pollution in Addis Ababa, Ethiopia by CEM. Based on the result of RPLM, respondents are WTP on average birr 90.34, 12.89 and 27.87 /respondent/year for additional level for river water quality, river water volume, and recreational facilities respectively.

Limaei et al. (2014) evaluated recreational and socioeconomic values of Masouleh forest park, north of Iran by using TCM. The average willingness to pay was 12,500 Iranian Rials per visit. Mekdes (2014) studied on visitors WTP for recreational use value of "Menagesha Suba" forest park by using contingent with the aim of valuing recreational benefits. At that time, mean WTP for recreational use value per visit per person in status quo and after improvement was ETB 46.2 and 91.9 respectively. The maximum WTP per visit was estimated to be ETB 44.63per visit for current condition and ETB 72.1 for proposed improvement.

Another researcher Ayana (2015) also studied on value of irrigation-water by eliciting farmers' WTP using CVM in Bahir Dar Zuria Woreda, Ethiopia. The study employed Single bounded and double bounded dichotomous choices with a follow up open-ended questions. From result of the study, mean WTP for the provision of improved irrigation water is found to be 674.5 and 579 Birr per year/0.25 ha from double bounded dichotomous and open-ended questions, respectively. The estimated aggregate WTP for improved irrigation water supply using DBDC and open-ended questions is found to be about birr $15,703,709$ and $13,480,278$ per year respectively. 
Adugna (2016) estimated the value of Nechisar National Park by using CEM found approximately birr 5.2, 8.79, 11.2 for domestic visitors and 7.7, 8.11, 35.87 for foreign visitors per visit per individual for afforestation, wildlife population and additional services respectively. These results are calculated from RPLM. The total value of the park was summed up to be 749,107,667 birr or US $\$ 35,876,804$.

Yidnekachew (2018) estimated value of Awash National Park by using TCM and CEM. The expected aggregate annual recreational economic benefit gained from visitors of the site is estimated at ETB 4,987,965.14. Tahzeeda et al., (2018) conducted a study on ecosystem goods and services for the National Botanical Garden, Bangladesh to suggest an appropriate entrance fee for park by assessing WTP. The result from TCM was 0.955 US dollars for entrance, and yearly consumer surplus was 593634.5 USD. From the CVM, it was 0.225 USD for the entrance and 0.376 USD for revenue maximizing entrance fee.

\section{Methodology}

\section{Description of the study area}

The study area covers the choke mountain range. The absolute location of the area extends between $10^{\circ}$ to $11^{\circ} \mathrm{N}$ and $37^{\circ} 30^{\prime}$ to $38^{\circ} 30^{\prime} \mathrm{E}$, the highest peak is located at $10^{\circ} 42^{\prime} \mathrm{N}$ and $37^{\circ} 50^{\prime} \mathrm{E}$, and it covers $17443 \mathrm{~km}^{2}$. The mountain is found in Ethiopian highlands with a peak elevation of more than $4000 \mathrm{~m}$ (Simane, Zaitchik, \& Ozdogan, 2013). In this area, the wetland ecosystems range from sedge swamps to seasonally flooded grasslands which cover above $3386 \mathrm{~km}^{2}$ (Teferi et al., 2010). The choke mountain wetlands ecosystem is source of several springs and rivers; it is main custodian of valuable water resources. 
Figure 3.1. Location of the study area

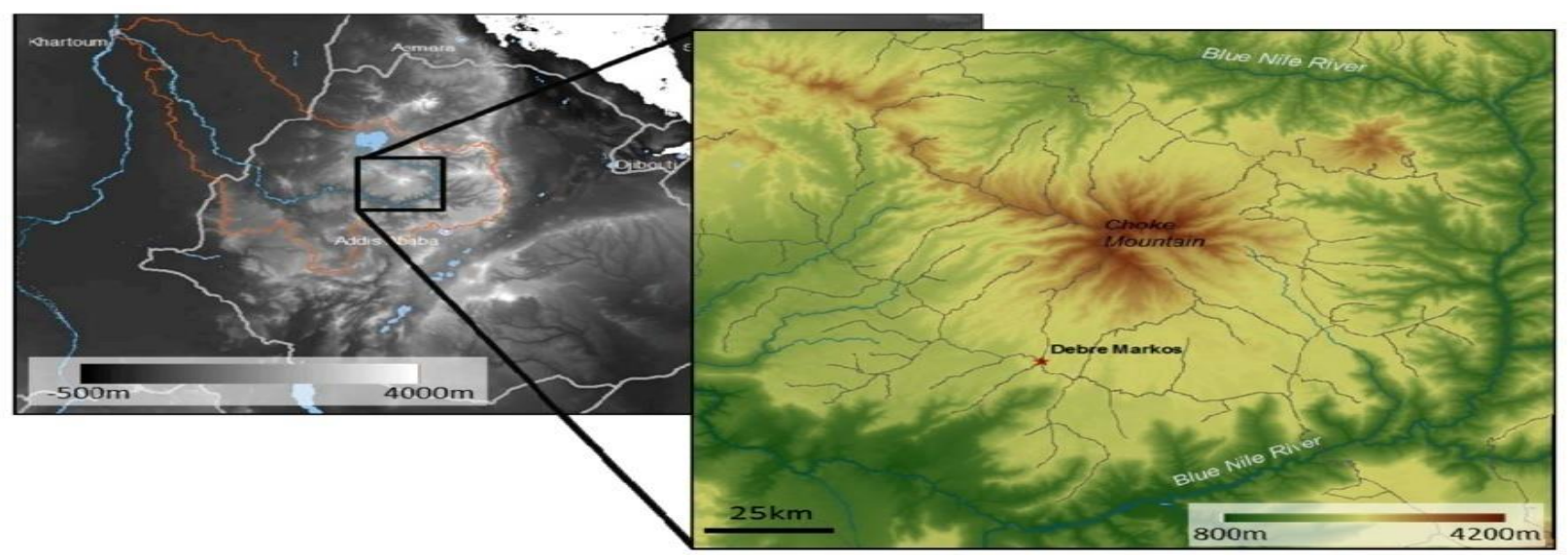

Source: (Simane et al., 2013)

The number of choice set, alternatives, blocks and largest attribute level determine required sample size in CE (Bekker-grob, 2015). In the study there was 9, 3, 2 choice sets, alternatives, and blocks respectively. The largest attribute level was 6 . Therefore, the study can determine sample size based on equation given below:

$\mathrm{n}=\frac{500 * \text { largest attribute level }}{\text { choice set } * \text { alternatives }} * B=\frac{500 * 6}{9 * 3} * 2=222$

Where, ' $\mathrm{n}$ ' is number of sample size, $B$ is number of blocks. The calculated result shows that at least 222 sample sizes are required to generate efficient result from the study. In the previous study, Getenet (2012) used 250-sample size to value the Choke mountain wetland ecosystem. The researcher restricted total sample size in to 270 , and it was distributed for two kebeles proportionally.

Table 3.1. Sample proportion

\begin{tabular}{|l|l|l|}
\hline Name of selected kebeles & Total number of households & Sample size from each kebeles \\
\hline Robu gebaya 02 & 1287 & $1287 \times \frac{270}{2461}=141$ \\
\hline Dangulie & 1174 & $1174 \times \frac{270}{2461}=129$ \\
\hline Total & 2461 & 270 \\
\hline
\end{tabular}

Source: Sinan woreda administration office, 2019 
There are four steps required in the design of a choice experiment: (i) definition of attributes, attribute levels and customization, (ii) experimental design, (iii) questionnaire development, and (iv) choice of sample and sampling strategy. The sample choice and sampling strategy is already discussed above.

Identifying the attributes and attribute levels is the first step to undertake choice experiment survey design (Mesfin, 2010; Getenet, 2012; Latinopoulos, 2014; Birol et al., 2006). This identifies residents' opinions about current issues and problems related to the mountain, and five attributes (biodiversity, water availability for domestic supply and irrigation, recreational quality, job opportunity and annual cost for service improvements) are selected to describe choke mountain wetland ecosystem.

\section{Table 3.2. Description of the attributes and their levels}

\begin{tabular}{|c|c|c|}
\hline Attribute & Description of Attributes & Levels of Attributes \\
\hline Biodiversity & $\begin{array}{l}\text { The number of common and endemic fauna } \\
\text { and flora species as well as their habitats in the } \\
\text { site. }\end{array}$ & $\begin{array}{l}\text { A) status quo: no change (very scarce) } \\
\text { B) Medium: improved by } 50 \%(\text { bd } 1) \\
\text { C) High: improved by } 75 \%(b d 2)\end{array}$ \\
\hline $\begin{array}{l}\text { Water availability for } \\
\text { domestic supply and } \\
\text { irrigation }\end{array}$ & $\begin{array}{l}\text { Availability of water for domestic } \\
\text { consumption and irrigation of crops. It is } \\
\text { measured in the number of pipe water, motor } \\
\text { for irrigation and dam. }\end{array}$ & $\begin{array}{l}\text { A) Status quo: no change (a few number of } \\
\text { pipe \& motors) } \\
\text { B) Medium: increased by } 50 \% \text { with } 1 \text { dam } \\
\text { construction (w1) } \\
\text { C) High: increased by } 100 \% \text { with } 2 \text { dam } \\
\text { construction (w2) }\end{array}$ \\
\hline Recreational quality & $\begin{array}{l}\text { The recreational facilities which attract both } \\
\text { local and foreign tourists to the mountain; } \\
\text { these are road, clean water, electricity resting } \\
\text { rooms, hotels and lodges, qualified tour } \\
\text { guide, toilet, information about the mountain } \\
\text { etc. }\end{array}$ & $\begin{array}{l}\text { A) Status quo: there are no such } \\
\text { facilities } \\
\text { B) Provision of clean water, electricity } \\
\text { road, hotels and lodge, resting rooms } \\
\text { and toilet only (rq1) } \\
\text { C) Provision of clean water, electricity, } \\
\text { road, hotels and lodge, resting } \\
\text { rooms, toilet, qualified tour guide, } \\
\text { information about the site etc. (rq2) }\end{array}$ \\
\hline
\end{tabular}




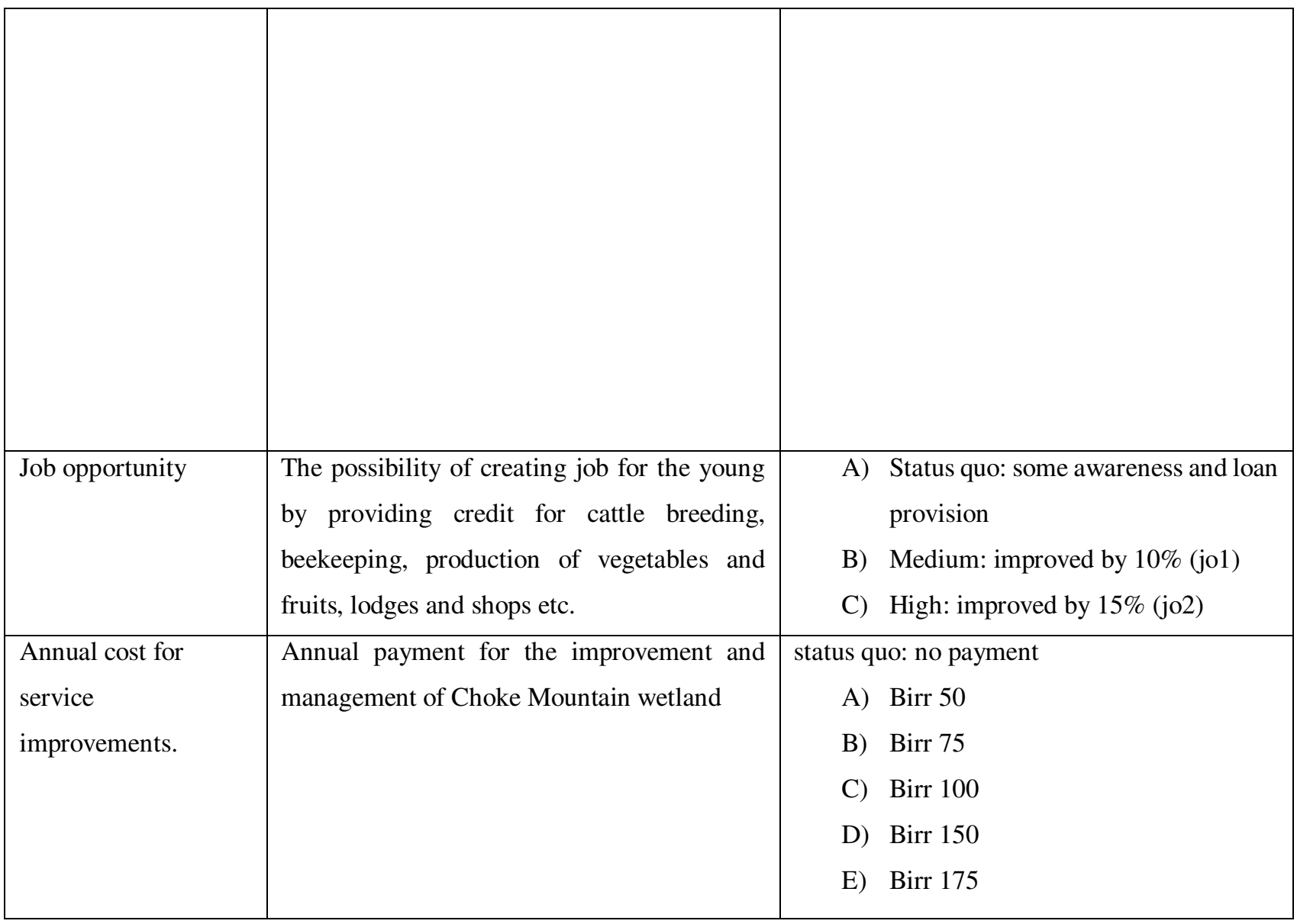

Table 3.3. Sample choice set

\begin{tabular}{|l|l|l|l|}
\hline Attribute & Status quo & Plan 1 & Plan 2 \\
\hline Biodiversity & Very scarce & Improved by 50\% & Improved by 75\% \\
\hline \multirow{2}{*}{$\begin{array}{l}\text { Water } \\
\text { availability }\end{array}$} & $\begin{array}{l}\text { A few numbers of pipes } \\
\text { and motors }\end{array}$ & $\begin{array}{l}\text { Inater and motors by 100\% } \\
\text { with 2 dam construction }\end{array}$ & $\begin{array}{l}\text { A few numbers of pipes } \\
\text { and motors }\end{array}$ \\
\hline
\end{tabular}




\begin{tabular}{|c|c|c|c|}
\hline $\begin{array}{l}\text { Recreation } \\
\text { quality }\end{array}$ & $\begin{array}{l}\text { There are no } \\
\text { qualified facilities }\end{array}$ & $\begin{array}{l}\text { There are no } \\
\text { qualified facilities }\end{array}$ & $\begin{array}{l}\text { Provision of clean water, } \\
\text { electricity, standardized } \\
\text { road, hotels and } \\
\text { lodge, resting rooms, } \\
\text { toilet, qualified tour guide, } \\
\text { information about the site } \\
\text { etc. }\end{array}$ \\
\hline $\begin{array}{l}\text { Job } \\
\text { opportunity }\end{array}$ & $\begin{array}{l}\text { Some awareness } \\
\text { And loan provision }\end{array}$ & $\begin{array}{l}\text { Provision of awareness } \\
\text { and loan increased by } 10 \%\end{array}$ & $\begin{array}{l}\text { Provision of awareness } \\
\text { and loan increased by } 10 \%\end{array}$ \\
\hline $\begin{array}{l}\text { Annual } \\
\text { payment }\end{array}$ & 0 ЕTB & 100 ЕTВ & 75 ETB \\
\hline $\begin{array}{l}\text { Choose one } \\
\text { and tick } \\
\operatorname{mark}(\sqrt{ })\end{array}$ & & & \\
\hline
\end{tabular}

The CEM is a variant of conjoint analysis, which was primarily developed by Louviere and Hensher (1982), and Louviere and Woodworth (1983), and has its roots in Lancaster's characteristics theory of value, in random utility theory and in experimental design (Latinopoulos, 2014). According to random utility theory (Luce, 1959; McFadden, 1973), utility function for a choice alternative $\mathrm{j}$ held by a respondent $\mathrm{i}\left(\mathrm{U}_{\mathrm{ij}}\right)$ is a function of the attributes of the alternatives presented to him/her $\left(Z_{\mathrm{ij}}\right)$ :

$\mathrm{U}_{\mathrm{ij}}=\mathrm{V}_{\mathrm{ij}}\left(\mathrm{Z}_{\mathrm{ij}}\right)+\mathrm{e}_{\mathrm{ij}}$

Where $\mathrm{Vij}$ is the systematic component related to the measurable component of utility and eij is random term, capturing effect of unobserved variables. Following Bennett and Blamey (2001) cited in Mesfin (2010), Feyisa \& Bersisa (2020) probability that respondent i would choose option g over option $\mathrm{h}$ is given by:

$\operatorname{Pr}\left(\mathrm{g} / \mathrm{C}_{\mathrm{i}}\right)=\operatorname{Pr}\left(\mathrm{U}_{\mathrm{ig}}>\mathrm{U}_{\text {ih }}\right)=\operatorname{pr}\left(\mathrm{V}_{\mathrm{ig}}+\mathrm{e}_{\mathrm{ig}}>\mathrm{V}_{\text {ih }}+\mathrm{e}_{\mathrm{ih}}\right), \mathrm{h} \in \mathrm{C}, \forall \mathrm{h} \neq \boldsymbol{g}$. 
The assumption is that stochastic components are independently and identically distributed (IID) with a Gumbel distribution. This leads to the use of MNL or CLM model to determine probabilities of choosing g over h options (Hanley, Mourato and Wright, 2001).

$\operatorname{Pr}\left(\mathrm{U}_{\mathrm{ig}}>\mathrm{U}_{\mathrm{ih}}\right)=\frac{\exp \text { BVig }}{\sum_{\boldsymbol{h}=1}^{H} \exp \text { BVih }}, \quad \mathrm{V}_{\mathrm{ig}} \neq \mathrm{V}_{\text {ih }}$ and, $\mathrm{h} \in \boldsymbol{C}$

Where, $\mathrm{Vi}$ is indirect utility function, and $\mathcal{B}$ is a scale parameter inversely related to the standard deviation of the error term means that the higher the scale parameter the lower the variance of the error term and hence the higher the model fits, and it is not separately identifiable in a single data set.

Utility may also depend on a set of individual socio-economic characteristics of respondent $\mathrm{i}$. However, since these characteristics are constant across choices for any given individual, they can only be entered as interaction terms (Hanley, Mourato, \& Wright, 2001). In that case, equation (1) takes the following form:

$\mathrm{U}_{\mathrm{ij}}=\mathrm{V}_{\mathrm{ij}}\left(\mathrm{Z}_{\mathrm{ij}}, \mathrm{S}_{\mathrm{ij}}\right)+\mathrm{e}_{\mathrm{ij}}$

Where, $S_{\mathrm{ij}}$ is a set of interaction terms between individual characteristics and alternative specific constant (ASC) which capture the mean effect of utility on any attribute not incorporated in choicespecific attributes (Birol et al., 2006).

The specification of the models in the study is expressed as follows:

$\mathrm{Vi}=\mathrm{ASC}+\mathrm{b} 1 \mathrm{BD}+\mathrm{b} 2 \mathrm{~W}+\mathrm{b} 3 \mathrm{RQ}+\mathrm{b} 4 \mathrm{JO}+\mathrm{b} 4$ Price (5) Basic model

Where: $\mathrm{ASC}=0$ for plan 3 (status quo option) and one for plan1 and plan2. In addition to this b1, b2, b3, b4and b5 are the coefficients associated with each of five attributes, i.e. improvement in biodiversity, availability of water for domestic supply and irrigation, recreation quality, job opportunity and annual cost for improvement respectively.

$\mathrm{Vi}=\mathrm{ASC}+\mathrm{b} 1 \mathrm{BI}+\mathrm{b} 2 \mathrm{~W}+\mathrm{b} 3 \mathrm{RQ}+\mathrm{b} 4 \mathrm{JO}+\mathrm{b} 5$ Price $+\lambda 1 \mathrm{ASCi} * \mathrm{AGE}+\lambda 2 \mathrm{ASCi} * \mathrm{SEX}+$ $\lambda 3 \mathrm{ASCi} * \mathrm{FAMZ}+\lambda 4 \mathrm{ASCi} * \mathrm{INC}+\lambda 5 \mathrm{ASCi}^{*} \mathrm{EDU}+\lambda 6 \mathrm{ASCi}^{*} \mathrm{OCC}+\lambda 7 \mathrm{ASCi}^{*}+\lambda 8 \mathrm{ASCi}{ }^{2} \mathrm{DSKM}$ 


\section{Random parameter /mixed logit model}

The MNL and CLM models come with main problems. First, they assume that no correlation among the unobserved disturbance terms; it relies on the assumption of independence of irrelevant alternatives (IIA) that cannot be always realistic. Second, it fails to take the taste variation of individuals in to considerations, and third it violates axioms of stability and transitivity consumer's choices (Olila, Nyikal, \& Otieno, 2015). However, RPLM (mixed logit model) is better since it takes in to account preference heterogeneity by allowing utility parameters to vary randomly and continuously over individuals and through interaction of the RPL model with individual's sociodemographic characteristics (Ibid). Therefore, IIA assumption is unnecessary in RPL model. The random utility function for the RPL model takes the following form:

$\mathrm{Uij}=\mathrm{Vij}+\mathrm{eij}=\mathrm{Zj}(\mathrm{b}+\gamma \mathrm{i})+\mathrm{eij}$

Where, Uij is the total utility for respondent $\mathrm{i}$ from choosing alternative $\mathrm{j}$ in the choice set; $\mathrm{Vij}$ is the systematic component of utility function, and eij is stochastic component of the utility function. The indirect utility is assumed a function of the choice attributes $\mathrm{Z}$ with parameters $\mathrm{b}$ and socioeconomic variables, which due to preference heterogeneity may vary across respondents by a random component $\gamma$ i. Age, family size, income, education, distance from the mountain, gender, occupation and information about the choke mountain wetland ecosystem included as socioeconomic variables. The probability that an individual $i$ choose alternative $j$ from each choice set is then presented as follows:

$\mathrm{Pij}=\frac{\exp Z i j(b+\gamma i)}{\sum_{n=1}^{N} \exp Z \operatorname{in}(b+\gamma i)}$

Each attribute's implicit price is the estimations of the WTP of respondents for an increase in the attribute (Getenet, 2012). Given that indirect utility function is linearly specified, the marginal value change of a single environmental attribute is calculated as a negative ratio of non-monetary attributes to monetary attributes with the following formula:

Implicit price $(\mathrm{WTP})=-(\beta$ non-market attribute of wetland $/ \beta$ monetary attribute $)$ 
Where, $\beta$ are the estimated coefficients of the attributes in multinomial or random parameter logit model. The compensating surplus relating to a change in overall conditions can be also estimated by using the following formula:

Compensating surplus (welfare change $)=-(1 / \beta$ monetary attribute $)(\mathrm{V} 0-\mathrm{Vi})$

Where, V0 is the indirect utility at status quo, Vi is indirect utility with different alternative improvement scenarios with their specific levels of the attributes, and $\beta$ is the estimated coefficient for monetary attribute.

Beyond welfare change, the study estimated marginal rate of substitution between non-monetary attributes. $\mathrm{MRS}_{\mathrm{xy}}$ represents the trade-offs between attributes. This can be calculated as the value of one attribute in terms of another attributes. $\mathrm{MRS}_{\mathrm{xy}}=\frac{M U_{x}}{M U_{y}}$ where, $M U_{x}$ indicates the marginal utility generated from an improvement of attribute " $\mathrm{X}$ " and $M U_{y}$ indicates the marginal utility generated from an improvement of attribute "Y".

\section{Results and discussion}

The study was conducted by using 270 households as a sample size. From the total, 193 are males and 77 are females. From the result, it is possible to understand the data was collected from households who are males and hard worker with mean ages of 37. Most of them are married and farmers. In addition to this, the result shows households are under low-income level. It can be expected by comparing their mean annual income and family size. As far as occupation is concerned, 64.44 percent of respondents were farmers, and 35.56 percent of households were nonfarmers. The mean income of households was Birr 80357.5 per year, and mean distance is approximately $7 \mathrm{Km}$.

Table 4.1 Descriptive Statistics of continuous socioeconomic characteristics of respondents

\begin{tabular}{|l|l|l|l|l|l|}
\hline Variable & Obs & Mean & Std. Dev. & Min & Max \\
\hline Age & 270 & 37.18519 & 10.43228 & 20 & 80 \\
\hline Family size & 270 & 3.740878 & 2.072877 & 1 & 10 \\
\hline Education & 270 & 7.126337 & 6.142304 & 0 & 23 \\
\hline Income & 270 & 80357.5 & 69931.86 & 5000 & 267719 \\
\hline Distance & 270 & 6.833801 & 4.589082 & .08 & 20 \\
\hline
\end{tabular}


Source: Authors computation, 2020

Table 4.2. Description of discrete socioeconomic variables

\begin{tabular}{|l|l|l|l|l|l|}
\hline Variable & Category & Frequency & Cumulative & percent & Cumulative \\
\hline \multirow{2}{*}{ Sex } & Female & 77 & 77 & 28.52 & 28.52 \\
\cline { 2 - 6 } & Male & 193 & 270 & 71.48 & 100 \\
\hline Marital status & Married & 205 & 205 & 75.93 & 75.93 \\
\cline { 2 - 6 } & Other & 65 & 270 & 24.07 & 100 \\
\hline Occupation & Farmer & 174 & 174 & 64.44 & 64.44 \\
\cline { 2 - 6 } & & 96 & 270 & 35.56 & 100 \\
\hline
\end{tabular}

Source: Authors computation, 2020

The choke mountain wetland provides so many advantages for households by providing clean air and water, by conserving the soil fertility, by providing foods for their domestic animals, and as a means of farmland. In addition to this, it is very important for carbon sequestration. It also supplies water for the Nile dam (it constitutes around 9.5 percent from the total). Direct consumption, animal grazing, irrigation, farmland and soil conservation are the benefits of choke mountain wetland ecosystem. Direct consumption includes purposes of the area for drinking water, recreation, wood and hunting. The responses are summarized in table 4.3 below.

Table 4.3. Descriptive statistics for the purpose of Choke mountain wetland ecosystem

\begin{tabular}{|l|l|l|l|l|l|}
\hline Degree & $\begin{array}{l}\text { Direct } \\
\text { consumption } \\
\text { in \% }\end{array}$ & $\begin{array}{l}\text { Animal } \\
\text { grazing in \% }\end{array}$ & $\begin{array}{l}\text { Irrigation in } \\
\%\end{array}$ & $\begin{array}{l}\text { Farmland in } \\
\%\end{array}$ & $\begin{array}{l}\text { Soil } \\
\text { conservation } \\
\text { in \% }\end{array}$ \\
\hline $1^{\text {st }}$ & 11.11 & 79.63 & 5.93 & 4.44 & 3.33 \\
\hline $2^{\text {nd }}$ & 35.19 & 11.11 & 22.96 & 5.93 & 20.37 \\
\hline $3^{\text {rd }}$ & 33.33 & 4.81 & 40.74 & 8.52 & 12.22 \\
\hline $4^{\text {th }}$ & 12.96 & 2.59 & 16.30 & 22.22 & 46.30 \\
\hline $5^{\text {th }}$ & 7.41 & 1.85 & 14.07 & 58.89 & 17.78 \\
\hline
\end{tabular}




\begin{tabular}{|l|l|l|l|l|l|}
\hline Total & 100 & 100 & 100 & 100 & 100 \\
\hline
\end{tabular}

Source: Authors computation, 2020

According to the study, most of households in surrounding area used choke mountain wetland for animal grazing. The second purpose was direct consumption. It is clear that there are several rivers and springs originate from mountain. Therefore, it is used as a source of water for drinking. Its geographical location, animals and plants, spiritual and historical places have a power to attract individual's attention.

Table 4.4. Descriptive statistics of the factors for the degradation of choke mountain wetland ecosystem

\begin{tabular}{|l|l|l|l|l|}
\hline Degree & $\begin{array}{l}\text { Overgrazing of } \\
\text { animals in \% }\end{array}$ & $\begin{array}{l}\text { Deforestation in } \\
\%\end{array}$ & Resettlement in \% & $\begin{array}{l}\text { Agricultural land } \\
\text { expansion in \% }\end{array}$ \\
\hline $1^{\text {st }}$ & 78.15 & 13.33 & 6.67 & 6.67 \\
\hline $2^{\text {nd }}$ & 12.22 & 53.70 & 12.22 & 12.22 \\
\hline $3^{\text {rd }}$ & 5.19 & 18.89 & 27.04 & 27.04 \\
\hline $4^{\text {th }}$ & 4.44 & 14.07 & 54.07 & 54.07 \\
\hline Total & 100 & 100 & 100 & 100 \\
\hline
\end{tabular}

Source: Authors computation, 2020

Overgrazing was ranked as first factor for degradation of the area since it was reported as most frequent problem by 78.15 percent of respondents. The reason behind the result is too many cattle are using the mountain as a source of grass, and they feed it throughout the year. This resulted in over degradation of the area. The livelihoods of the farmers around the mountain highly depend on livestock rearing and farming. The second major problem was deforestation because farmers are using forests of mountain for construction of houses and fuel wood etc. The remaining factors, resettlements and agricultural land expansion problems, were ranked equally next to overgrazing and deforestation. 
Table 4.5. Descriptive statistics of the awareness of households for choke mountain wetland ecosystem services

\begin{tabular}{|l|l|l|l|}
\hline Awareness & Frequency & Percent & Cumulative \\
\hline Very good & 93 & 34.44 & 34.44 \\
\hline Good & 138 & 51.11 & 85.56 \\
\hline Poor & 39 & 14.44 & 100.00 \\
\hline Total & 270 & 100 & \\
\hline
\end{tabular}

Source: Authors computation, 2020

The people who have enough awareness about the choke mountain wetland ecosystem services constitute around 34.44 percent. It covers $1 / 3$ of the total respondent. The choke mountain wetland ecosystem service has a public good nature. Goods and services that have a public good nature are affected with a problem of the tragedy of the common.

Table 4.6. Descriptive statistics of the responsible agents for the degradation of choke mountain wetland ecosystem services

\begin{tabular}{|l|l|l|l|}
\hline Responsible agent & Freq & Percent & Cumulative \\
\hline Farmers & 37 & 13.70 & 13.70 \\
\hline Government & 13 & 4.81 & 18.52 \\
\hline Farmers and government & 220 & 81.48 & 100.00 \\
\hline Total & 270 & 100.00 & \\
\hline
\end{tabular}

Source: Authors computation, 2020

The study shows both government and farmers are responsible for degradation of choke mountain wetland ecosystem services. It constitutes 81.48 percent of total respondent. The farmers should be led by rules and regulations set by government agent, and all should think for future not present satisfaction only. 
Table 4.7. Results of the follow up questions

\begin{tabular}{|l|l|l|l|}
\hline & Follow up questions & Frequency & Percent \\
\hline 1. & I select the status quo option because of hostility to the payment. & 35 & 12.96 \\
\hline 2. & $\begin{array}{l}\text { I found that the attributes of job opportunity are important and } \\
\text { select the plan with the highest level of this attribute. }\end{array}$ & 40 & 14.5 \\
\hline 3. & $\begin{array}{l}\text { I am interested the alternative with the highest level of all } \\
\text { attributes whatever the payment level is. }\end{array}$ & 133 & 49.3 \\
\hline 3. & $\begin{array}{l}\text { I select a plan which have some improvement with low payment } \\
\text { (I found that the attributes of biodiversity are important and select } \\
\text { the plan with the highest level of this attribute. }\end{array}$ & 25 & 11.5 \\
\hline 5. & $\begin{array}{l}\text { I found that the attributes of recreational quality are important and } \\
\text { select the plan with the highest level of this attribute. }\end{array}$ & 6 & 9.3 \\
\hline
\end{tabular}

As summarized in table 4.7 above, 12.96 percent of respondent replied that they do not agree to pay for any improvement because of payment hostility. About 14.5, 9.3 and 2.22 percent of them made their choices with the highest level the attributes of job opportunity, biodiversity and recreational quality respectively.

The random parameter logit model can solve problem of violation of IIA assumption. Therefore, model is estimated in to account for IIA assumption and unobservable preference heterogeneity across respondents.

Table 4.10: The result of basic mixed logit

\begin{tabular}{|l|l|l|l|}
\hline Variables & Coefficient & Std. Err. & Z \\
\hline Mean & & & \\
\hline
\end{tabular}




\begin{tabular}{|c|c|c|c|}
\hline ASC0 & 31.38685 & 5979.981 & 0.01 \\
\hline price & -.0117239 & .0015783 & $-7.43 *$ \\
\hline bd2 & 2.263494 & .1761907 & $12.85 *$ \\
\hline bd3 & 3.169127 & .2105115 & $15.05 *$ \\
\hline w2 & 1.759457 & .16459 & $10.69 *$ \\
\hline w3 & 1.48025 & .1899772 & $7.79^{*}$ \\
\hline $\mathrm{rq} 2$ & 2.356006 & .175866 & $13.40 *$ \\
\hline $\mathrm{rq} 3$ & 2.595485 & .185066 & $14.02 *$ \\
\hline jo2 & 2.111469 & .1921653 & $10.99 *$ \\
\hline jo3 & 2.305142 & .2118605 & $10.88^{*}$ \\
\hline \multicolumn{4}{|l|}{ SD } \\
\hline $\mathrm{bd} 2$ & .1752102 & .2261114 & 0.77 \\
\hline bd3 & 1.112887 & .1973021 & $5.64^{*}$ \\
\hline w2 & -.3184872 & .1764845 & $-1.80 * * *$ \\
\hline w3 & .7803876 & .2221975 & $3.51^{*}$ \\
\hline $\mathrm{rq} 2$ & 1.010204 & .2171479 & $4.65^{*}$ \\
\hline $\mathrm{rq} 3$ & .5903329 & .2669111 & $2.21 * *$ \\
\hline jo2 & 1.073901 & .2150859 & $4.99 *$ \\
\hline jo3 & -1.322214 & .2519059 & $-5.25^{*}$ \\
\hline Mixed logit model & & Number of obs $=$ & 7290 \\
\hline
\end{tabular}




\begin{tabular}{|l|l|l|l|}
\hline AIC $=2197.994$ & LR chi2(8) $=$ & 81.98 & \\
\hline Log likelihood = -1080.9969 & & Prob > chi2 $=$ & 0.0000 \\
\hline
\end{tabular}

Source: Authors computation, 2020

The result of mixed logit model shows all non-monetary attributes of choke mountain wetland ecosystem are positive and statistically significant at 1 percent level of significance.

Based on result in table 4.10, there is preference variation over alternatives in mixed logit model. It is indicated by standard deviation of attribute levels. The significance of standard deviation of model shows advantage of mixed logit model. The mixed logit model estimation result tells significance and large derived standard deviation for all attribute levels except bd2. This indicates that data supports choice specific unobserved heterogeneity for these attribute levels. The result shows that standard deviation of bd3, w3, rq2, jo2 and jo3 attribute levels statistically significant at 1 percent level of significance, and he remaining rq3 and w2 are statistically significant at 5 percent and 10 percent level of significance respectively.

However, mixed logit model cannot show source of heterogeneity. Therefore, estimating mixed logit model with interaction is necessary.

\section{Table 4.11: Mixed logit model with interaction}

\begin{tabular}{|l|l|l|l|}
\hline Variables & Coefficient & Std. Err. & $\mathrm{Z}$ \\
\hline ASC0 & 31.60438 & 5794.859 & 0.01 \\
\hline price & -.0117764 & .0015755 & $-7.47^{*}$ \\
\hline bd3_inc & $-2.31 \mathrm{e}-06$ & $1.76 \mathrm{e}-06$ & -1.31 \\
\hline bd3_sex & .0258929 & .2885329 & 0.09 \\
\hline bd3_occ & -.6676491 & .5095752 & -1.31 \\
\hline bd3_mars & -.5000912 & .3532689 & -1.42 \\
\hline bd3_dskm & .0089256 & .0334806 & 0.27 \\
\hline
\end{tabular}




\begin{tabular}{|c|c|c|c|}
\hline bd3_edu & .0019118 & .0421383 & $0.05 * *$ \\
\hline bd3_famz & .3169583 & .0968682 & $3.27 *$ \\
\hline bd3_age & .0044922 & .0169267 & 0.27 \\
\hline w3_inc & $-1.74 \mathrm{e}-06$ & $2.09 \mathrm{e}-06$ & -0.83 \\
\hline w3_age & .028861 & .0171352 & $1.68 * * *$ \\
\hline w3_sex & .1308563 & .2849587 & 0.46 \\
\hline w3_occ & -1.302855 & .5234274 & $-2.49 * *$ \\
\hline w3_edu & -.0017499 & .0408336 & -0.04 \\
\hline w3_famz & .054646 & .0947393 & 0.58 \\
\hline w3_dskm & -.0007422 & .0317073 & -0.02 \\
\hline w3_mars & .6126347 & .3551141 & 1.73 \\
\hline rq2_inc & $1.61 \mathrm{e}-07$ & $1.99 \mathrm{e}-06$ & 0.08 \\
\hline rq2_age & -.0011351 & .0177456 & -0.06 \\
\hline rq2_sex & -.1014808 & .2885464 & -0.35 \\
\hline rq2_mars & -.634487 & .3557453 & $-1.78^{* *}$ \\
\hline rq2_edu & .0153902 & .0416689 & 0.37 \\
\hline rq2_famz & .2523327 & .0979242 & $2.58^{*}$ \\
\hline rq2_occ & .3762299 & .5110536 & 0.74 \\
\hline rq2_dkm & .0123185 & .0310565 & 0.40 \\
\hline rq3_inc & $-4.32 \mathrm{e}-06$ & $1.81 \mathrm{e}-06$ & -2.39 \\
\hline
\end{tabular}




\begin{tabular}{|c|c|c|c|}
\hline rq3_age & .0116151 & .0174787 & 0.66 \\
\hline rq3_sex & .2364178 & .2923069 & 0.81 \\
\hline rq3_mars & .285603 & .3628672 & 0.79 \\
\hline rq3_famz & .048514 & .0969784 & 0.50 \\
\hline rq3_edu & .0124138 & .0420998 & 0.29 \\
\hline rq3_occ & -.3079505 & .5237473 & $\mid-0.59$ \\
\hline rq3_dkm & .0075289 & .0313627 & 0.24 \\
\hline jo2_inc & $-2.94 e-06$ & $2.20 \mathrm{e}-06$ & -1.34 \\
\hline jo2_age & -.0326937 & .0204489 & -1.60 \\
\hline jo2_sex & .1874545 & .3372544 & 0.56 \\
\hline jo2_mars & -.6684664 & .41886 & -1.60 \\
\hline jo2_famz & -.1810285 & .1111925 & -1.63 \\
\hline jo2_occ & 1.861025 & .6279922 & $2.96^{*}$ \\
\hline jo2_edu & -.0048626 & .0499211 & -0.10 \\
\hline jo2_dskm & -.0402697 & .0346197 & -1.16 \\
\hline jo3_inc & $7.85 \mathrm{e}-07$ & $2.74 \mathrm{e}-06$ & 0.29 \\
\hline jo3_age & -.0684036 & .0218893 & $-3.12^{*}$ \\
\hline jo3_sex & -.4811802 & .3592706 & -1.34 \\
\hline jo3_mars & -.2566415 & .4509681 & -0.57 \\
\hline jo3_famz & -.1240045 & .1198015 & -1.04 \\
\hline
\end{tabular}




\begin{tabular}{|l|l|l|l|}
\hline jo3_occ & .8646615 & .6432629 & 1.34 \\
\hline jo3_edu & -.0493952 & .0511704 & -0.97 \\
\hline jo3_dskm & -.0815716 & .0369497 & $-2.21^{* *}$ \\
\hline bd2 & 2.347467 & .1825284 & $12.86^{*}$ \\
\hline w2 & 1.761468 & .1652238 & $10.66^{*}$ \\
\hline bd3 & 2.861212 & .9642432 & $2.97^{*}$ \\
\hline w3 & .7036757 & .9041194 & 0.78 \\
\hline rq2 & 1.662703 & .9178024 & $1.81^{* * *}$ \\
\hline rq3 & 2.06998 & .9261273 & $2.24^{* *}$ \\
\hline jo2 & 3.687188 & 1.089551 & $3.38^{*}$ \\
\hline jo3 & 6.10128 & 1.154276 & $5.29^{*}$ \\
\hline Mixed logit model & & Number of obs $=$ & 7290 \\
\hline AIC = 2149.811 & LR chi2(6) $=$ & 41.00 & \\
\hline Log likelihood = -1009.7692 & & Prob > chi2 $=$ & 0.0000 \\
\hline S & & & \\
\hline
\end{tabular}

Source: Authors computation, 2020

The interaction of biodiversity and recreational quality with family size is positive and statistically significant at 1 percent level of significance. This implies that as number of family size increase, their willingness to choose improved level of biodiversity and recreational quality also increase. This indicates that households consider payment for improvement of attributes; payment per each family member is low compared with benefit they gain as number of family size increase.

The interaction between improved level of water availability and age the respondent is positive and statistically significant at 10 percent level of significance. This shows that effort of individual 
to fetch water from springs or rivers and to use the river for irrigation without modern machine is decline as their age rise; therefore, they need improvement in water availability service.

The interaction of job opportunity with age of respondent and distance from mountain to house is negative at 1 percent and 5 percent level of significance. This implies that demand of individuals for creation of job opportunity declines when their age increase and their house far away the mountain.

The interaction between recreational quality and individual being married is negative. This tells that individuals who have gotten marriage have lower preference for improved recreational quality as compared with single, divorced, widowed and others. The rationality behind this result is that married individuals, particularly in rural area have not that much free time to refresh themselves. Mostly they spend their free time with in a house or by visiting their relatives. In addition to this, the result shows that these households do not give attention for income generated from tourists. The income levels of the household have also negative relationship with the improvement of recreational quality.

The other significant interaction is between water availability and occupation. The result shows that farmer is less likely to preferred improved water availability attribute as compared with merchants, public sector employees, private sector employees and others. This can be because of lack of fertile and enough farmland for irrigation. Furthermore, fetching water from rivers and springs is easy for farmers than others. As the interaction between job opportunity and occupation shows, farmers need job opportunity compared with others.

Table 4.13 MWTP from mixed logit model

\begin{tabular}{|l|l|}
\hline Attribute levels & MWTP \\
\hline bd2 & 193.06743 \\
\hline bd3 & 270.31446 \\
\hline w2 & 150.07499 \\
\hline w3 & 126.25963 \\
\hline
\end{tabular}




\begin{tabular}{|l|l|}
\hline rq2 & 200.95833 \\
\hline rq3 & 221.38495 \\
\hline jo2 & 180.10024 \\
\hline jo3 & 196.61984 \\
\hline
\end{tabular}

Source: Authors computation, 2020

An improvement of biodiversity helps to improve water supply, recreational services and creation of job opportunity. Therefore, it is able to be a backbone for improvement of other attributes. However, it is not used for such purpose compared to its potential due lack of infrastructural development. Therefore, improving recreational quality helps to use full potential of site in area of ecotourism. In addition to this, improvement of job opportunity helps to increase income level of the households. The productivity of crop is low due to acidic nature of soil and cold weather condition of the area. Therefore, from the respondents' point of view improving job opportunity is better than improving water availability.

From the estimated result of marginal WTP, it is possible to derive total WTP by using probit model. By assuming individuals' willingness to pay is normally distributed, total WTP is ETB 7,133,034.216 and 7,031,211.146 per year for first and second improvement alternatives respectively. The maximum amount of money that households willing to pay for improvement of choke mountain wetland ecosystem, and first improvement alternative is preferred to second one.

Marginal rate of substitution is trade-off between non-monetary attributes estimated from the model, or it indicates that scarification of one attribute improvement to gain an additional improved level of another best alternative attributes keeping others constant. This can be calculated as $\mathrm{MRS}_{\mathrm{xy}}=\frac{M U_{x}}{M U_{y}}$ where $M U_{x}$ marginal utility derived from attribute $\mathrm{X}$ and $M U_{y}$ is marginal utility derived from another attribute $\mathrm{Y}$. In this study, $M U_{x}$ (in vertical) and $M U_{y}$ (in horizontal) stand for coefficients of attribute levels estimated from the mixed logit model.

Table 4.14. Estimation of MRS

\begin{tabular}{|l|l|l|l|l|l|l|l|l|}
\hline Levels & bd2 & bd3 & w2 & w3 & rq2 & rq3 & jo2 & jo3 \\
\hline
\end{tabular}




\begin{tabular}{|l|l|l|l|l|l|l|l|l|}
\hline bd2 & 1 & 0.714 & 1.286 & 1.53 & 0.96 & 0.87 & 1.072 & 0.982 \\
\hline bd3 & 1.4 & 1 & 1.8 & 2.14 & 1.345 & 1.22 & 1.5 & 1.37 \\
\hline w2 & 0.78 & 0.55 & 1 & 1.189 & 0.746 & 0.678 & 0.83 & 0.763 \\
\hline w3 & 0.654 & 0.467 & 0.84 & 1 & 0.628 & 0.57 & 0.7 & 0.64 \\
\hline rq2 & 1.04 & 0.74 & 1.34 & 1.6 & 1 & 0.907 & 1.116 & 1.02 \\
\hline rq3 & 1.146 & 0.82 & 1.475 & 1.753 & 1.101 & 1 & 1.23 & 1.126 \\
\hline jo2 & 0.933 & 0.666 & 1.2 & 1.426 & 0.896 & 0.813 & 1 & 0.916 \\
\hline jo3 & 1.02 & 0.727 & 1.31 & 1.557 & 0.987 & 0.888 & 1.092 & 1 \\
\hline
\end{tabular}

Source: Authors computation, 2020

From the above table, value of biodiversity attribute expressed in terms of water availability attribute is highest relative to other trade-offs estimated in this study. This implies that households scarify more of water availability improvement to gain an additional improved level of biodiversity attribute at citrus paribus. The second highest trade-off is between recreational quality and water availability attribute. This also tells that households scarify more of water availability improvement to gain an additional improved level recreational quality, but they scarify more water availability improvement to get additional improved level of biodiversity than recreational quality improvement. The third highest trade-off is between improvement of job opportunity and improvement of water availability attributes. The trade-off between improvement of biodiversity and recreational quality is lower relative to the trade-off biodiversity with other attributes. This indicates that respondents scarify relatively less recreational quality improvement to gain an additional improved level of biodiversity.

Economic welfare measurement is calculated as the difference between the individuals' utilities that could be achieved under the status quo and changed scenario alternatives. To compute the welfare change, first, the values of the attributes in the status quo alternatives are substituted into the indirect utility function. Next, the values of the attributes in changed situation of scenarios are substituted into the indirect utility function, and then after the value of the alternative with a 
changed situation are subtracted from the value in the status quo alternative. Lastly multiplying this by the negative inverse of the coefficient of the monetary attribute gives welfare change (Ali,

2011). Mathematically, Welfare change $=-\frac{1}{p_{\beta}}\left(V_{0}-V_{i}\right)$ where $p_{\beta}$ is the coefficient of monetary cost attribute, $V_{0}$ and $V_{i}$ indirect utility estimated from status quo and improved scenario respectively.

Two alternative scenarios have been developed to illustrate the overall WTP for improvements with respect to status quo:

\section{Current situation/Status quo levels}

$\checkmark$ Biodiversity is very scarce

$\checkmark$ There are a few numbers of pipes and motors

$\checkmark$ There are no qualified infrastructural facilities

$\checkmark$ Some awareness and loan provision

\section{Improvement scenario one (high improvement scenario)}

$\checkmark$ Biodiversity is improved by 75 percent

$\checkmark$ Increasing the number of pipes and motors by 100 percent with 2 dam construction

$\checkmark$ There is a provision of clean water, electricity, standardized road, hotels and lodge, resting rooms, toilet, qualified tour guide, information about the site etc.

$\checkmark$ Provision of awareness and loan increased by 15 percent

\section{Improvement scenario two (medium improvement scenario)}

$\checkmark$ Biodiversity is improved by 50 percent

$\checkmark$ Increased the number of pipes and motors by 50 percent with 1 dam construction

$\checkmark$ There is provision of clean water, electricity, standardized road, hotels and lodge, resting rooms and toilet only

$\checkmark$ Provision of awareness and loan increased by 10 percent

Table 4.15. The results of estimated welfare change

\begin{tabular}{|l|l|}
\hline Scenario & WTP per year in Birr \\
\hline
\end{tabular}




\begin{tabular}{|l|l|}
\hline Improvement scenario one & $2,119,457.028$ \\
\hline Improvement scenario two & $1,955,828.606$ \\
\hline
\end{tabular}

The result from table 4.15 is interpreted as the price that households are willing to pay for change from status quo to corresponding improved scenarios. WTP for improvement scenario one is obtained as ETB 2,119,457.028 per year, and improvement scenario scored ETB 1,955,828.606. This implies implementation of improvement scenario one and improvement scenario two through policy intervention will generate ETB 2,119,457.028 and 1,955,828.606 welfare gain respectively. Therefore, implementation of improvement scenario one is preferable to obtain more welfare change.

\section{Conclusion}

Choke mountain wetland ecosystem is found in Ethiopia, Amhara region East Gojam zone. It is the source of several springs and rivers; it is the main custodian of valuable water resources. It covers the 9.5 percent of Upper Blue Nile River that supplies water for millions of downstream Nile basin countries particularly Sudan and Egypt. Therefore, valuing this wetland ecosystem is useful for different purposes and at different scales in support of wetland wise use management and decision-making.

The objective of the study was to value of choke mountain wetland ecosystem. Choice experiment valuation method is preferable in the study because choice experiment valuation method has the ability to estimate both use and non-use values each attribute of wetland ecosystems. These attributes in the study are biodiversity, recreational quality, water availability, job opportunity and annual monetary payment. Choke mountain wetland ecosystem services compared to the current situation; they gave higher value for biodiversity improvement than the remaining attributes. However, the monetary cost is negative and significant in mixed logit models. This indicates that as cost of improving mountain's wetland ecosystem services higher, probability of households to prefer improved alternative becomes lower.

The marginal WTP of water availability is lowest compared with other attributes because improvement of biodiversity increases the potential of the choke mountain wetland ecosystem to supply water, and improvement of recreational quality also satisfy demand for households to clean 
water. The total WTP for the first and second improvement alternatives was ETB 7,133,034.216 and 7,031,211.146 respectively; it was high in first improvement alternative. Furthermore, compensating surplus which reflect overall willingness to pay for change from status quo to alternative improvement scenarios were valued. Estimated results for improvement scenario one and two were ETB 2,119,457.028 and 1,955,828.606 respectively. This indicates that implementation of the improvement scenario one is preferable to obtain more welfare change. The study also estimated marginal rate of substitution between non-monetary attributes. The trade-off between biodiversity and water availability was dominated over the other trade-offs. The second highest trade-offs are between recreational quality and water availability followed by trade-off between job opportunity and water availability.

\section{Reference}

Adugna, E. (2016). Economic valuation of Nechisar national park ecosystem: Choice experiment approach.

Alam, K. (2005). Valuing the environment in developing countries : Problems and potentials.

Ali, Y. (2011). Valuing the Economic Benefit of Ecotourism Areas With Travel Cost and Choice Experiment Methods: a Case Study of Semen Mountain National Park, Ethiopia.

Andualem, G. (2011). Estimating the Economic Value of Wildlife: The Case of Addis Ababa Lions Zoo Park. Addis Ababa.

Assessment, M. E. (2005). Ecosystems and human well-being: synthesis. Washington, DC: Island Press.

Ayana, A. (2015). Eonomic Valuation of Irrigation Water in Bahir Dar Zuria Woreda, Ethiopia: The Case of Chilal Abay, Negida and Upper Andasa Irrigatioon Schemes.

Bahar, Ç. E., \& Jian, X. (2015). The valuation of forest product annd service in Turkey in case of Bulu forest area. 18 .

Barbier, E. B., Acreman, M., \& Knowler, D. (1997). Economic Valuation of Wetlands. A guide for olicy makers and planners .

Bekker-grob, E. W. (2015). Sample Size Requirements for Discrete-Choice Experiments in Healthcare : a Practical Guide. Practical Appliation.

Birol, E., Karousakis, K., \& Koundouri, P. (2006). Using a choice experiment to account for preference heterogeneity in wetland attributes : The case of Cheimaditida wetland in 
Greece. 0. https://doi.org/10.1016/j.ecolecon.2006.06.002

Bishop, Romano, R. \&, \& D. (1998). Environmental Resource Valuation, Applications of the Contingent Valuation Method in Italy. In (Boston MA: Kluwer Academic Publishers).

Carlsson, F., Frykblom, P., \& Liljenstolpe, C. (2003). Valuing wetland attributes : an application of choice experiments. 47, 95-103. https://doi.org/10.1016/j.ecolecon.2002.09.003

Cools, J., Johnston, R., Hattermann, F. F., Douven, W., \& Zsuffa, I. (2013). Tools for wetland management : Lessons learnt from a comparative assessment. Environmental Science and Policy, 34, 138-145. https://doi.org/10.1016/j.envsci.2013.01.013

Dagnew, M., \& Aboytu, S. (2015). Wetlands Potential, Current Situation and Its Threats in Tana Sub-Basin, Ethiopia. World Journal of Environmental and Agricultural Sciences Vol. 1, No, $1-14$.

De, G. R., Stuip, M., Finlayson, M., \& Davidson, N. (2006). Valuing Wetlands: guidance for valuing the benefits derived from wetland ecosystem services. Ramsar Convention Secretariat, Gland, Switzerland \& Secretariat of the Convention on Biological Diversity, Montreal, Canada. ISBN 2-940073-31-7: Ramsar Technical Report No. 3/CBD Technical Series No. 27.

Diafas, I. (2014). Estimating the Economic Value of forest ecosystem services using stated preference methods : the case of Kakamega forest, Kenya. (May).

Dora, C. V., \& Francisco, A. (2011). The Case of the Toro 3 Hydroelectric Project and the Recreo Verde Tourist Center in Costa Rica. 6.

Emerton, L. (2016). Economic Valuation of Wetlands: Total Economic Value. 4.

Feyisa, B., \& Bersisa, M. (2020). Valuation of Wetland Attributes: An Application of Choice Experiment Approach : A Case Study of Lake Koka. 8(5), 76-85. https://doi.org/10.11648/j.jim.20190805.11

Gebretsadik, T. (2014). Economic Valuation of Protecting Urban River Water Pollution in Addis Ababa, Ethiopia: A Choice Experiment Approach.

Getahun, G. (2010). Determinants of Residents Willingness to Pay for Improved Urban Environment: Choice Modeling Approach. Addis Ababa.

Getinet, S. (2017). Status of Wetland Ecosystems in Ethiopia and Required Actions for Conservation. 32, 92-100.

Getnet, B. (2012). Valuation of Choke Mountain Range Wetland Ecosystem, East Gojjam, Amhara Region, Ethiopia: Application of Choice Experiment Valuation Method Getnet. Addis Ababa. 
Gilbert, S. W. (2013). Applying the Hedonic Method. National Institute of Standards and Technology Technical Note 1811 .

Gossaye, A. (2007). Households' Willingness To Pay for Improved Water Services in DebreZeit Town, Ethiopia. Addis Abeba.

Groot, R. S. De, Wilson, M. A., \& Boumans, R. M. J. (2002). A typology for the classification, description and valuation of ecosystem functions, goods and services. 41, 393-408.

Hanley, N., Mourato, S., \& Wright, R. E. (2001). Choice Modelling Approaches : A Superior Alternative for Environmental Valuation? 15(3).

Hawkins, K. (2003). Economic Valuation of Ecosystem Services. (October).

Herath, S., \& Maier, G. (2010). The hedonic price method in real estate and housing market research : a review of the literature.

Hussein, A., \& Jennifer, R. (1998). Environmental Valuation: A Worldwide Compendium of Case Studies Edited by. (26).

Ibrahim, M., \& Minwyelet, M. (2018). Status , Threats and Management of Wetlands in the Lake Tana Sub- basin : A Review. 3, 23-45.

Israel, M., \& Timar, M. (2018). Wetland ecosystems in Ethiopia and their implications in ecotourism and biodiversity conservation. Journal of Ecology and The Natural Environment, 10(August), 80-96. https://doi.org/10.5897/jene2017.0678

Kassaye, H. (2014). Assessment of spatio-temporal changes of wetlands using GIS and RS techniques in Dawa Chefa Area in the Northern Central Ethiopian Highlands. Mekelle University College.

Latinopoulos, D. (2014). Using a choice experiment to estimate the social benefits from improved water supply services. 8168. https://doi.org/10.1080/1943815X.2014.942746

Limaei, S. M., Ghesmati, H., Rashidi, R., \& Yamini, N. (2014). Economic evaluation of natural forest park using the travel cost method (case study; Masouleh forest park, north of Iran ). 2014(6), 254-261.

McCartney, M., Rebelo, L.-M., Sellamuttu, S. S., \& Silva, S. d. (2010). Wetlands, Agriculture and Poverty Reduction. Colombo, Sri Lanka: International Water Management Institute.

Mekdes, T. (2014). Analysis of Visitors Willingness to Pay for Recreational Use Value of "Menagesha Suba" Forest Park: Application of Contingent Valuation Method.

Mekonnen, G., \& Yared, W. (2018). Reversing the Degradation of Ethiopian Wetlands": Is it Unachievable Phrase or A Call to Effective Action? Environmental science and natural resource Volume 14(5), 1. 
Meya, J. N., Drupp, M. A., Baumgartner, S., \& Quaas, M. F. (2017). Economic Inequality and the Value of Nature. Economics working paper, No.2017-08, 4.

Mesfin, G. (2010). "Estimating the Economic Value of a Recreational Wetland Ecosystem Using Travel Cost and Choice Experiment Methods: An Application toWondo Genet." Addis Ababa.

Mohammed, A. (2007). Recreation Use Value of Wondo Genet Wetland Ecosystem - Ethiopia.

Nega, A. (2012). Valuing the Economic Benefit of Irrigation Water: Application of Choice Experiment and Contingent Valuation Methods to Ribb Irrigation and Drainage Project in South Gonder, Ethiopia.

Olila, D. O., Nyikal, R. A., \& Otieno, D. J. (2015). What Do Farmers Want from Crop Insurance Schemes: AStated Preference Approach . International conference of agriicultural economists .

Pascal, D. C., \& Daniel, H. (2019). Economic valuation of ecosystem conservation at the Taravo river basin in Corisca with the application of a discrete choice experiment.

Price, R. (2007). An Introductory Guide o Valuing Ecosysem Services. 12.

Rahel, E., \& Adeba, G. (2017). Valuing the Benefits of Recreational Wetland Ecosystem: An Application of Contingent Valuation and Travel CostMethods: The Case of Boye Recreational Wetland, Jimma Zone, Oromia National Regional State, Ethiopia. Journal of Resources Development and Management Vol.29.

Ramachandra, T., Rajinikanth, R., \& Ranjini, V. (2004). Economic Valuation of Wetlands. Journal of Environmental Biology .

Robin, N. (2008). The Role of Economic Valuation in he Conservation of Tropical Nature. 3.

Sander, H. A., \& Haight, R. G. (2012). Estimating the economic value of cultural ecosystem services in an urbanizing area using hedonic pricing. Journal of Environmental Management, 113, 194-205. https://doi.org/10.1016/j.jenvman.2012.08.031

Simane, B., Zaitchik, B. F., \& Ozdogan, M. (2013). Agroecosystem Analysis of the Choke Mountain Watersheds, Ethiopia. 592-616. https://doi.org/10.3390/su5020592

Sintayehu, A. A. (2015). Assessment of the Potentials Tourism Resources of Choke Mountain and its Environs, Ethiopia. Journal of Tourism \& Hospitality .

Stefano, P., \& Bishop, J. (2004). Assessing the Economic Value of Ecosystem Conservation. (101).

Tadessse, A., \& Solomon, A. (2014). A review of Wetland Conservation and Management Policy in Ethiopian. International Journal of Scientific and Research Publications, 4(9), 1- 
6.

Tahzeeda, J., Khan, M. R., \& Bashar, R. (2018). Environmental \& Socio-economic Studies. 1-9. https://doi.org/10.2478/environ-2018-0001

Teferi, E., Uhlenbrook, S., Bewket, W., Wenninger, J., \& Simane, B. (2010). The use of remote sensing to quantify wetland loss in the Choke Mountain range, Upper Blue Nile basin, Ethiopia. Hydrol. Earth Syst. Sci., 14, 2415-2428, 2.

Teshager, M. (2019). EconomicValuation of Agro biodiversity and Its Determinant in West Gojjam Zone, Amhara Region Ethiopia: Choice experiment Approach.

Tim, E., Ishwaran, M., Gian, P. A., \& Alex, R. (2010). Economic Growth and the Environment. 31.

USACE. (1987). Wetlands Delineation Manual, Technical report.Y-87-1,Department of the Army, Washington, D.C. 9.

Yidnekachew, A. (2018). Estimating the Economic Value of Ecotourism Areas: A Case Study of Awash National Park, Ethiopia.

Yonghua, T., Duian, L., Jie, C., Deganga, W., Yunyun, X., \& We, i. M. (2018). Valuation of environmental improvements in coastal wetland restoration: A choice experiment approach.

Global Ecology and Conservation volume 15 .

Zedler, J. B., \& Kercher, S. (2005). Wetland Resources : Status, Trends , Ecosystem Services , and Restorability. 39-74. https://doi.org/10.1146/annurev.energy.30.050504.144248

Zelalem, Y., \& Rao, N. (2015). Economic Analysis of Household prefferences for Wetland Attributes: Application of Choice Experiment to the Case of Lake Tana Wetlands. International Journal of Application or Innovation in Engineering \& Management, 4(11), $1-15$. 
Figures

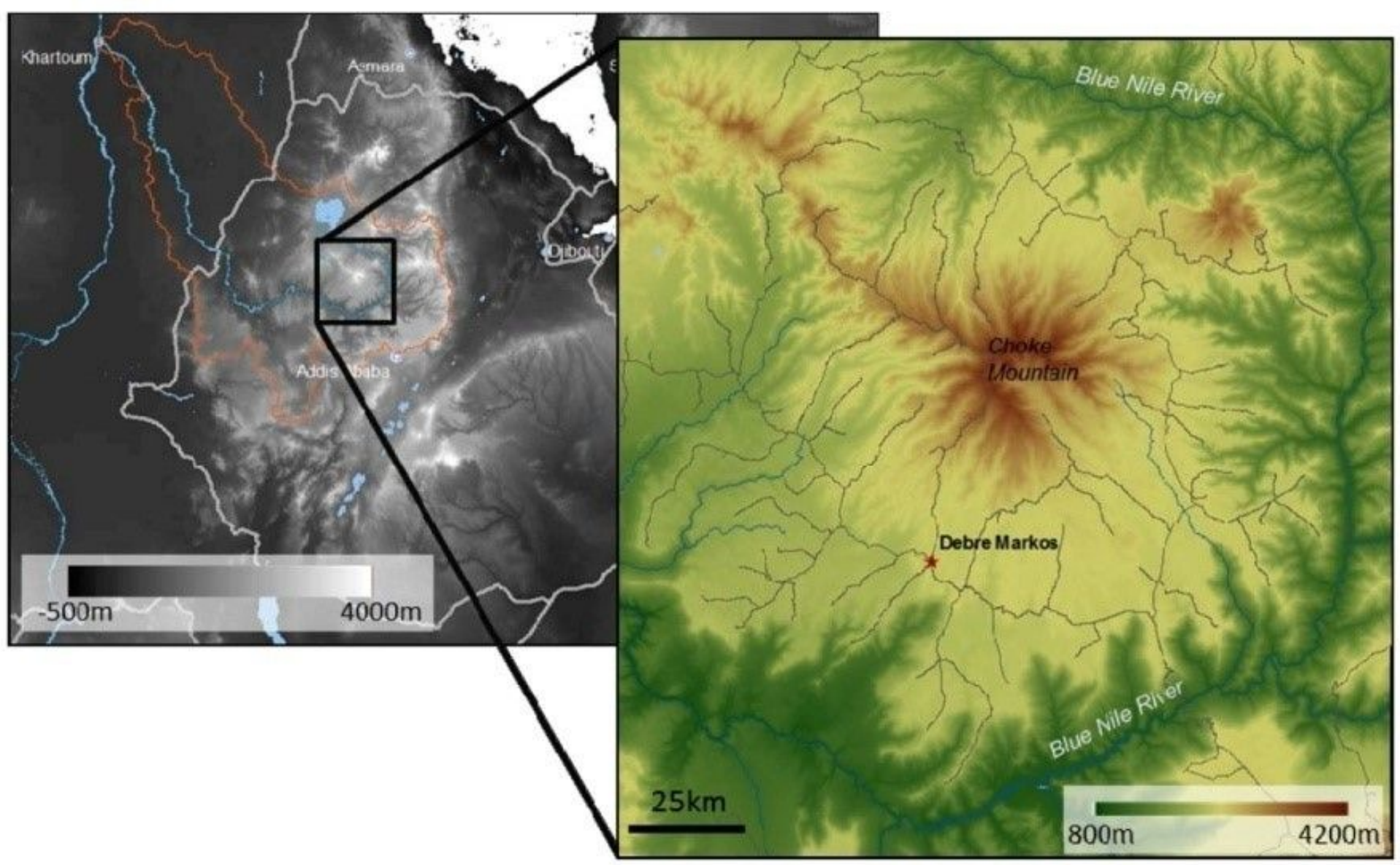

Figure 1

3.1. Location of the study area 